\title{
THE IMPORTANCE OF GENDER EQUALITY IN MAINTAINING SOCIAL JUSTICE AND WOMEN'S CONTRIBUTION TO THE DEVELOPMENT OF SOCIETIES
}

\author{
Oydinoy Marat Qizi Ergasheva
}

4th Year Student Of English Language And Literature Jizzaz State Pedagogical Institute, Uzbekistan

\section{ABSTRACT}

Although we have information about the unique participation of women in politics in every period of human history, it is the truth that the right and opportunity to do so in public administration does not apply to every woman in society and is not guaranteed by legal norms.

Ancient Greek poets, such as Socrates, Aristotle, and Plato, referred to the city as the best state in which equality and justice reigned in society. as the best laws, they also put forward laws that guaranteed everyone equality. Applying the idea of equality between men and women in his writings, the Greek scholar Antifont stated, "Nature creates all: women and men equally, but people develop laws that make people unequal." Abu Nasr al-Farabi, one of the encyclopedic scholars of the East, in his City of Noble People, described a state that ruled equality as a state that aspired to virtue recognized as entitled.

KEYWORDS: - Independence, Constitution of the Republic of Uzbekistan, United Nations Convention, gender equality, rule of law, privileges, social and political life, women's rights.

\section{INTRODUCTION}

It should be noted that in the XX-XXI centuries in many countries of the world the participation of women in politics has expanded. In particular, the process of electing women to the presidency, prime minister, diplomat, deputy and other positions will intensify. Studies have shown that women's participation in the social and political life of society allowed the state to work on the basis of democratic principles and to resolve all issues fairly.

Today, the world community is also trying to create international mechanisms that correctly understand the role of women in human development. The adoption by the UN General Assembly on 18 December 1979 of the
Convention on the Elimination of All Forms of Discrimination against Women is proof of our view. The Convention is a key document that clearly defines the issues related to the achievement of practical equality between women and men, ie gender equality, the exercise of their rights by women in practice.

\section{THE MAIN FINDINGS AND RESULTS}

The problems set out in the Convention are multifaceted. It identifies the urgency of the problem of ending discrimination in various forms, as well as important rules for enhancing the status of women as equal persons, their political, socio-economic and cultural rights, equality with men, motherhood reflected.

After gaining independence, the Republic of 
Uzbekistan also included the issue of equality of men and women among the issues to be addressed in the first place, and enshrined it in the Constitution of the Republic of Uzbekistan. In particular, Articles 18 and 46 of our encyclopedia describe: "In the Republic of Uzbekistan, all citizens have the same rights and freedom, regardless of gender, race, nationality, language, religion, social origin, e. they are equal in the circle of the law, regardless of their religion, personal and social status.

Privileges are established only by law and must be in accordance with the principles of social justice. " (Article 18 of the Constitution of the Republic of Uzbekistan).

In order to ensure equality of citizens, this article of the Constitution stipulates that privileges shall be established by law and shall be in accordance with the principle of social justice. This means that benefits are provided only in cases specified by law. It leads to the determination of social justice. It is not possible to grant privileges to citizens based on their class, party, national, or religious affiliation. As a result of this rule, the poor and economically vulnerable part of the population is financially supported during the formation of market relations. This will make it easier for citizens to be economically different. Equality in the circle of the law and equal rights and freedoms of citizens allow them to find their place in social life, to use their full potential, to participate equally in the affairs of state and society, in economic life. Any violation of the equal rights and equality of citizens before the law shall be prohibited and, if any, shall be prosecuted.

Article 46 of the Constitution of the Republic of Uzbekistan states that "women and men have equal rights [1]."

Numerous legal instruments and measures have been enacted to ensure the equality of women and men in practice. These are, on the one hand, when women have equal opportunities as men for education, occupation, employment, remuneration, active participation in the sociopolitical life of the country, on the other hand, taking into account the role of women in the family, physical capabilities, it is seen in the establishment of favorable conditions and privileges for their work, health. Two things, on the one hand, are equal opportunities, and on the other hand, women's equal rights are ensured by creating additional conditions and benefits for women. If women are not given the right to education, employment, and participation in political life, and are not given additional privileges to exercise these rights, such equality will make them suffer rather than benefit them. The reason: women have a huge role in the family and their physical abilities are not the same as men. If women do not devote enough time to family affairs, their most important task raising children - will suffer. It is also detrimental to society. Therefore, the benefits include the creation of all-round convenience for women in the family.

Based on the Constitution of the Republic of Uzbekistan, in order to further strengthen gender equality, the Law of the Republic of Uzbekistan "On Guarantees of Equal Rights and Opportunities for Women and Men", adopted on September 2, 2019, was developed and implemented.

With this law, for the first time, the concept of "gender" was defined in our national legislation.

According to him, the main directions of state policy in the field of equal rights and opportunities for women and men, the mechanisms of public administration in this area have been identified.

In particular, in order to prevent gender discrimination against women, the Commission on Gender Equality was established in the Republic of Uzbekistan. 
The main tasks of the Commission are to implement a unified state policy in the field of equal rights and opportunities for women and men, to participate in the development and implementation of state programs, national action plans and strategies in this area. Cooperation with international organizations, relevant bodies of foreign countries in the field of providing information to the Oliy Majlis of the Republic of Uzbekistan, ensuring equal rights and opportunities for women and men and compliance with international standards in this regard [2].

In addition, the Cabinet of Ministers of the Republic of Uzbekistan adopted a resolution "On measures to implement national goals and objectives in the field of sustainable development until 2030."

At the same time, in the framework of the Fifth Sustainable Development Goal, Uzbekistan has developed nine tasks on "Ensuring gender equality and empowering all women."

In line with the objectives of the Fifth Goal (Gender Equality), by 2030, eliminate all forms of discrimination against all women, ensure full and effective participation of women at all levels of decision-making in political, economic and social life, and equal opportunities for leadership. riding is necessary. In addition, this goal includes the introduction of the principles of gender equality in the process of adopting State programs at different levels of the state [3].

With $49 \%$ of the population being women and about $64 \%$ of them being women under the age of 30 , it is necessary to pursue a separate state policy in this direction, and this policy pursued by the head of state is self-sufficient. We can also see that it is justified. In particular, in his speech at the 75th anniversary session of the United Nations (UN) General Assembly on September 23, 2020, President Shavkat Mirziyoyev said, "Gender equality policy has become a priority for us. The role of women in public administration is growing. The number of women deputies in our new Parliament has doubled, "she said, referring to the work being done in the country on women's policy [4].

\section{Conclusion}

In conclusion, the concept of gender does not only represent the interests of women. Representatives of both sexes have their own dreams and The same opportunity to take bold steps towards goals, strengthen health, improve quality of life he just claims to give. This is a market that surrounds the world like a spider's web the ruthless games of the economy are very important in our lives in accordance with the requirements. Do we want whether or not we have to keep pace with the world community. Otherwise, the sick person is out of society we are cut off from the new world. When people who have seen a lot reach out in prayer, of course there is a wish to be said: "Let our warm place not be lost." The role of both men and women in society have This aspect of the issue should also be kept in mind when considering gender equality.

In addition, it is necessary to increase the legal, economic and spiritual knowledge of women.

\section{REFERENCES}

1. O`zbekiston Respublikasi Konstitutsiasi. Toshkent. Adolat. 2019 year.

2. Yoshlar ta'lim-tarbiyasi uchun qo'shimcha sharoitlar yaratish, xotin-qizlar bandligini oshirishga qaratilgan kompleks choratadbirlarni o'z ichiga olgan 5 ta tashabbus loyihasi. 03.04.2019.

3. Barhayot hayot maqsadlari loyihasi. 
CURRENT RESEARCH JOURNAL OF HISTORY 2(6): 49-52, June 2021

DOI: https://doi.org/10.37547/history-crjh-02-06-11

ISSN 2767-472X

(C)2021 Master Journals

Crossref do) 80 Google

Accepted 22 th June, 2021 \& Published 27thJune, 2021

https://www.uz.undp.org/content/uzbeki stan/uz/home/post-2015.html.

4. https://www.gazeta.uz/oz/2020/09/23/b $\mathrm{mt} /$

5. O’zbekiston Respublikasining "Xotin-qizlar va erkaklar uchun teng huquq hamda imkoniyatlar kafolatlari to`g`risida"gi qonun. Toshkent. 02.09.2019.

6. A.Karimov. Yuksak manaviyat yengilmas kuch. 2008 year. 46 pages.

7. Sh.M.Mirziyoyev. Erkin va farovon demokratik 0 'zbekiston davlatini birgalikda barpo etamiz. 18.11.2018.

8. Sh.M.Mirziyoyev.Yangi O`zbekistonda erkin va farovon yashaylik. 18.12.2020.

9. https://www.lex.uz

10. https://www.kun.uz 